\title{
WITH ARISTOTELIANS LIKE THESE, WHO NEEDS ANTI-ARISTOTELIANS? CHYMICAL CORPUSCULAR MATTER THEORY IN NICCOLÒ CABEO'S METEOROLOGY
}

\author{
CRAIG MARTIN \\ De Wulf-Mansion Centre, K.U. Leuven*
}

\begin{abstract}
Niccolò Cabeo, a Jesuit based in Northern Italy, wrote a massive commentary on Aristotle's Meteorology that was first printed in 1646. The central concepts of this work emerged from the chymical philosophy of his time. Cabeo advocated a corpuscular matter theory that integrated Paracelsian principles and Aristotelian elements. Furthermore, he rejected the application of metaphysics and mathematics to natural philosophy. Instead he promoted experiential and experimental practices, including chymical ones, to investigate what he called the "real physical" world. Cabeo's epistemology sustained his adaptation of Aristotle, whereby substantial forms have no explanatory role, but matter and form are two different kinds of substances that differ with respect to the size of their constituent corpuscles and their forces. Maintaining the need to use Aristotle as a foundation, Cabeo relied on his unique interpretations of the text of the Meteorology in order to demonstrate that his matter theory was not alien to Aristotelianism.
\end{abstract}

Ever since Charles Schmitt showed that there were multiple Renaissance Aristotelianisms, the vibrant and self-critical nature of Peripatetics has been recognized. ${ }^{1}$ Recent scholarship has amply demonstrated that the seventeenth-century rejection and replacement of Aristotelian natural philosophy was not a sudden gestalt switch. Rather, a number of savants, such as Descartes, Gassendi, and Hobbes, who claimed to overturn traditional ways of explaining nature, nevertheless relied on the concepts and vocabulary

* I thank Katharine Park, Christoph Lüthy, and an anonymous reader for their advice and comments. Research and writing of this article was funded by a Rockefeller Fellowship at the History of Science Department, University of Oklahoma, Villa I Tatti, and the FWO at K.U. Leuven.

${ }^{1}$ For self-criticism among Aristotelians, see: Ian Maclean, "Foucault's Renaissance Episteme Reassessed: An Aristotelian Counterblast," Journal of the History of Ideas 59 (1998), 149-166. For the vitality of the Peripatetic line of thought, see: Christia Mercer, "The Vitality and Importance of Early Modern Aristotelianism," The Rise of Modern Philosophy, ed. Tom Sorrell (Oxford, 1993), 33-67. 
of the schoolmen. ${ }^{2}$ Similarly, movements within the Aristotelian framework gave rise to developments in the works of the novatores. Examples include Giacomo Zabarella's logic, which, it is argued, influenced, among others, Francis Bacon and his emphasis on induction, and Sennert's corpuscular hylomorphism, which contributed to the eventual rise of atomism. ${ }^{3}$

In a number of works William R. Newman and Lawrence M. Principe have shown that seventeenth-century corpuscular natural philosophies grew out of the medieval alchemical tradition, by following Geber's Summa perfectionis, which emphasized the creation of new substances through partes minimae and utilized experimental tests as evidence for the existence of these corpuscles. The Geberian line of thought is found in the writings of Daniel Sennert, the Wittenberg physician and professor. Sennert contended that his tests demonstrated the corpuscular nature of matter. Moreover, he believed that corpuscularian thought was not at odds with Aristotelian precepts. In his later writings, adopting Avicenna's position on the nature of mixture, he argued that the corpuscular constituents of mixtures remain intact, that is, do not lose or have diminished their substantial forms. Similarly George Starkey, the American physician and chymist, combined scholastic hylomorphism and Geberian corpuscular matter theory in his chymical practice. The works of both Starkey and Sennert

${ }^{2}$ Dennis Des Chene, Physiologia: Natural Philosophy in Late Aristotelian and Cartesian Thought (Ithaca, 1996); Roger Ariew, Descartes and the Last Scholastics (Ithaca, 1999); Cees Leijenhorst, The Mechanisation of Aristotelianism: The Late Aristotelian Setting of Thomas Hobbes's Natural Philosophy (Leiden, 2002); Margaret Osler, "Renaissance Humanism, Lingering Aristotelianism and the New Natural Philosophy: Gassendi on Final Causes," in Humanism and Early Modern Philosophy, ed. Jill Kraye and M. W. F. Stone (London, 2000), 193-208.

${ }^{3}$ For Sennert see: Michael Stolberg, "Particles of the Soul: The Medical and Lutheran Context of Daniel Sennert's Atomism," Medicina nei secoli n.s. 15 (2003), 177-203; Emily Michael, "Sennert's Sea Change: Atoms and Causes," in Late Medieval and Early Modern Corpuscular Matter Theories, ed. Christoph Lüthy, John E. Murdoch, and William R. Newman (Leiden, 2001), 331-362; William R. Newman, "Corpuscular Alchemy and the Tradition of Aristotle's Meteorology, with special reference to Daniel Sennert," International Studies in the Philosophy of Science 15 (2001), 145-153; Kurd Lasswitz, Geschichte der Atomistik, (Hamburg/Leipzig, 1890) I: 436-454. For Bacon and Zabarella see: A. C. Crombie, Robert Grosseteste and the Origins of Experimental Science 1100-1700 (Oxford, 1953), 300-303; Antonio PerezRamos, Francis Bacon's Idea of Science and the Maker's Knowledge Tradition (Oxford, 1988), 225-238; Lisa Jardine, Francis Bacon: Discovery and the Art of Discourse (Cambridge, 1974), 54-58. 
influenced Robert Boyle, and thus are key to understanding the development of seventeenth-century matter theory. ${ }^{4}$

The studies of Newman and Principe have brought to light the intertwining of Aristotelian and chymical matter theories and their presence in elite circles of natural philosophy during the seventeenth century. ${ }^{5}$ There remain, however, doubts over the degree to which Geber influenced early modern chymistry. ${ }^{6}$ Equally, the scope of experientially based chymical matter theory during the first half of the seventeenth century is not fully known. The contents of Niccolò Cabeo's Commentaria in libros Meteorologicorum (1646, reprinted 1686), however, demonstrate that chymical matter theory and Geberian experimental procedures spread into the Aristotelian commentary tradition and was developed not just in ultramontane Europe, England, and its colonies, but also in Italy. ${ }^{7}$ Cabeo's corpuscular theory, which he contended was supported by chymical practice and experiments, stands out because of his rejection of metaphysical speculation in general and of substantial forms specifically, in addition to his attempt to reconcile Aristotle and Paracelsus.

The middle years of the seventeenth century witnessed much diversity and complexity in Aristotelian natural philosophy, where qualifiers such as 'strict', 'conservative', 'secular', and 'Jesuit' cannot always be applied with any definite meaning. Cabeo's commentary on Aristotle's Meteorology is perhaps one of the most

${ }^{4}$ William R. Newman, "Experimental Corpuscular Theory in Aristotelian Alchemy: From Geber to Sennert," in Late Medieval and Early Modern Corpuscular Matter Theories, 291-329; William R. Newman and Lawrence M. Principe, Alchemy Tried in the Fire: Starkey, Boyle, and the Fate of Helmontian Chymistry (Chicago, 2002), 18-34; William R. Newman, Gehennical Fires: The Lives of George Starkey, an American Alchemist in the Scientific Revolution (Cambridge, Mass., 1994), esp. 20-53, 92-114; id., "The Alchemical Sources of Robert Boyle's Corpuscular Philosophy," Annals of Science 53 (1996), 567-585; id., "Boyle's Debt to Corpuscular Alchemy," in Robert Boyle Reconsidered, ed. Michael Hunter (Cambridge, 1994), 177-192.

${ }^{5}$ On the use of the word "chymistry" see: William R. Newman and Lawrence M. Principe, "Alchemy vs. Chemistry: The Etymological Origins of a Historiographic Mistake,” Early Science and Medicine 3 (1998), 32-65; Niccolò Cabeo, the subject of this paper, used the terms "chimicus" and "chymicus" interchangeably.

${ }^{6}$ For a discussion of these doubts, see: Newman and Principe, Alchemy Tried in the Fire, 249.

${ }^{7}$ Most studies on seventeenth-century corpuscular chymistry focus almost entirely on northern Europe. E.g., Clericuzio, Elements, Principles and Corpuscles: A Study of Atomism and Chemistry in the Seventeenth Century (Dordrecht, 2000); Newman and Principe, Alchemy Tried in the Fire. 
difficult pieces of Aristotelian commentary literature to classify. It is innovating, yet takes pain to maintain traditional forms of argumentation, retaining Aristotle as a starting point for investigations into nature. Nevertheless, many of Cabeo's ideas resonate with the positions of the novatores: he was in favor of Paracelsian matter theory and was a proponent of the use of chymical testing; just like Descartes, he argued for the elimination of substantial forms as a conceptual tool in natural philosophy; in line with the Neostoics, he thought form was an active spirit, yet entirely material; similarly to Francis Bacon, he chastised those who were overly concerned with words rather than physical objects and urged researchers to penetrate into the depths of nature. In other respects, however, Cabeo cannot be seen as a participant of some of the seventeenth-century movements that defined the development of modern science: he neither promoted a mechanical conception of the universe, nor tolerated the intrusion of mathematics into physics; and although he conceded that reliance on philosophical or exegetical commentary was insufficient, he insisted on writing a literal commentary on Aristotle. Yet again, the Aristotle that Cabeo emphasized was atypical for most Aristotelians of his time.

Cabeo (1585-1650) was a Jesuit who studied and taught at Parma, Mantua, Bologna, and Ferrara among other locales in northern Italy, working both in colleges as well as courts. ${ }^{8} \mathrm{He}$ was successful in both arenas and went from being known as a child prodigy to eventually gaining a reputation as a "grand' huomo, famous in print." Cabeo's learning gained him entry into Ferdinando Gonzaga's ducal court where he was on familiar terms with the Duke himself. ${ }^{9}$ His fame from print derived from his only two published works: the Philosophia magnetica, published in 1629, which is best known for its anti-Copernican stance, its explanation of magnetic and electrical phenomena as caused by effluvia, and its attacks on Gilbert's contentions of the magne-

${ }^{8}$ For his location in particular years see Ugo Baldini, "L'altro polo dell'attività scientifica: La provincia veneta," in Legem impone subactis (Rome, 1992), 427-434; id., "I Gesuiti nelle corti padane (1600-1650)," in Saggi sulla cultura della Compagnia di Gesù (secoli XVI-XVIII) (Padua, 2000), 171-211. For Cabeo's biography see: A. Ingegno, "Niccolò Cabeo," in Dizionario biografico degli italiani (Rome, 1972), XV, 686-688.

${ }^{9}$ Giuseppe Gorzoni, Istoria del collegio di Mantova della compagnia di Gesù, ed. Antonella Bilotto and Flavio Rurale (Mantova, 1997), 146. 
tism of the earth. ${ }^{10}$ His second printed piece, the Commentaria, expanded the number of topics treated and discussed a wide variety subjects as well as Aristotle's text in its lengthy four volumes.

The scarce existing literature on Cabeo's work takes two main approaches. According to the first, he is a philosopher who "used traditional Aristotelian arguments."11 The second takes its vision from J. L. Heilbron's assessment of Cabeo's two books as "important" works of the scientific revolution. ${ }^{12}$ Thus, Cabeo's relation to Galileo has been explored, and his writings are considered important for his alleged contribution to discovery of the isochronism of pendula, their discussion of the laws of motion, and the description of the experiments that Cabeo and Giovanni Battista Baliani carried out in Parma, whereby they concluded that the velocity of falling objects is independent of weight and increases with time. ${ }^{13}$ Both views of Cabeo fail to convey any sense of what the Commentaria's larger purpose was. Cabeo created an Aristotelian natural philosophy that was to be concerned strictly with material bodies composed of corpuscles; its epistemological foundation was to be experiential and experimental.

Cabeo separated physica, as he called it, from the other two subjects he considered part of speculative science: metaphysics and mathematics. ${ }^{14}$ For him physica concerns the sensible prop-

${ }^{10}$ Martha R. Baldwin, "Magnetism and the Anti-Copernican Polemic," Journal for the History of Astronomy 16 (1985), 155-174; Peter Dear, Discipline and Experience: The Mathematical Way in the Scientific Revolution (Chicago, 1995), 63-67

${ }_{11}$ Baldwin, "Magnetism," 157; Dear also stresses Cabeo's adherence to "proper Aristotelian" methodology, Discipline and Experience, 64-66.

${ }^{12} \mathrm{~J}$. L. Heilbron, Electricity in the $17^{\mathrm{th}}$ and $18^{\mathrm{th}}$ Centuries (Berkeley/Los Angeles, 1979), 180-183.

${ }^{13}$ On Cabeo's relation to Galileo see: Ledo Stefanini, "1611: Mantova incrocio di arte, scienza e politica," Atti e memorie. Accademia nazionale virgiliana di scienze lettere $e$ arti, n.s. 71 (2003), 69-99; on his role in the discovery of the pendulum's isochronism see: Maria Teresa Borgato, "Riccioli e la caduta dei gravi," in Giambattista Riccioli e il merito scientifico dei Gesuiti nell'età barocca, ed. Maria Teresa Borgato (Firenze, 2002), 91-102; on his collaboration with Baliani see: Serge Moscovici, L'Expérience du mouvement: Jean-Baptiste Baliani disciple et critique de Galilée (Paris, 1967), 49ff; Maria Teresa Borgato, "Niccolò Cabeo tra teoria ed esperimenti: le leggi del moto," in Gesuiti e università in Europa (secoli XVI-XVIII), ed. Gian Paolo Brizzi and Roberto Greci (Bologna, 2002), 361-385; Borgato, "Riccioli e la caduta dei gravi," 85-91; Dear, Discipline and Experience, 67-76.

${ }^{14}$ Niccolò Cabeo, Commentaria in libros Meteorologicorum (Rome, 1646), I, 6: "Supponendum igitur est tres iam communiter ab omnibus distingui scientias totales speculativas Methaphysicam, Physicam, \& Mathematicam, quae dicuntur scientiae totales." 
erties of physical bodies and their effects, that is, "all of the effects of those things that can be perceived," and "the sensible causes of all effects, which can be perceived by external sensation," while "those [causes] that cannot be perceived do not pertain to physica." ${ }^{15}$ Equating the real with physical and material objects, he contended that metaphysical concepts have no bearing on our understanding of the natural world. Because the goal of physica is to explain sensible causes and effects, Cabeo largely appealed to observation, experience, and contrived experiments. The experiential emphasis of the Commentaria was not lost on his contemporaries. Marin Mersenne, in a letter to Athanasius Kircher, written shortly after the Commentaria's publication, stated: "what [Cabeo] wrote on the Meteors is certainly beautiful, for he does not follow the commonplaces of philosophers, but what he judges best according to experiences." ${ }^{16}$ Although Francis Bacon is often credited with initiating experimental natural philosophy, it rose from more than one location and its inspiration was varied. For Cabeo, who as far as I know did not read Bacon, experimental natural philosophy stemmed from the centuries-old tradition of Aristotelian alchemy; he did not try to create a novum organum, but rather tried to use old foundations and new experiences to revive an old science.

\section{A new Aristotelian natural philosophy}

Cabeo's advocay of corpusclar matter theory and chymical interventions into nature underpinned an attempt to reform Aristotelian natural philosophy. This reform took into account contemporary theories and practices, but kept reading Aristotle as foundational.

15 Ibid., I: 9: “Omnes ergo illis effectus, qui sensu percipi possunt, \& de facto sensu percipiantur horum omnium effectuum cognoscendi ratio spectabit ad Physicam, \& ex complexione cognitionum harum proprietatum, \& effectuum integrabitur Physica, quae tota versatur in hoc ut ostendat causas sensibiles omnium effectuum, qui sensu externo percipi possunt, \& quae sic percipi non possunt non spectabunt ad Physicam...”;

16 Marin Mersenne, Correspondance du P. Marin Mersenne, religieux minime, ed. Cornélis de Waard and Armand Beaulieu (Paris, 1932-1988), XIV: 473, letter ŭ 1514 (22 September 1646): "Certe pulcra sunt de Meteoris quae scripsit, neque enim sequitur vulgus philosophorum, sed quod iuxta experientias optimum judicat." For his favorable view of this work, see also letter ŭ 1528 to André Rivet (11 October 1646), XIV: 524: "Nous avons un nouveau commentaire en 2 volumes sur les Meteores d'Aristote fort excellent, du Jesuiste Cabeus, imprimé à Rome..." 
As a result his natural philosophy appropriated recent discoveries, yet potentially remained palatable to conservatives. His reform was composed of two interrelated platforms. First, like so many other seventeenth-century philosophers, he decried what he understood to be the dependence on and faith in Aristotle's authority. Second, he maintained Aristotle's injunction against metabasis, i.e., the transfer of methods and models from one subject to another, and from this concluded that physica should be free of metaphysical and mathematical explanations. ${ }^{17}$ In Cabeo's eyes, Aristotle himself had been too occupied with metaphysics, and dependence on his writings had caused Peripatetics to ignore physical objects, or to analyze nature using metaphysical concepts. On the other hand, his attacks on mathematics were directed at novatores, who in their use of mathematical demonstrations failed to show how these abstractions related to physical causation.

Cabeo's attacks on other Peripatetics is made complex by the fact that he is one as well and insisted, despite some reservations, that an accurate understandings of Aristotle's text, in this case the Meteorology, had to constitute the starting point for physica. Since philosophical truths, according to Cabeo, should be independent "from authority," and based instead on "evident reason," 18 true philosophy must go beyond the acts of "reading (lectio), commentary (commentatio), or speculation (speculatio)." 19 Indeed, other commentators have been led astray by trying to solve Aristotle's obscurities without personally experiencing nature and thus adopted a religion (fides) of Aristotelianism rather than a science (scientia) based on observation..$^{20} \mathrm{He}$ was particularly wary of bibliolaters who thought that establishing the meaning of the

\footnotetext{
17 Aristotle, Posterior Analytics 75a38-75b6. On the history of this prohibition and its eventual rejection see: Amos Funkenstein, Theology and the Scientific Imagination (Princeton, 1986), 299-327.

18 Cabeo, Commentaria, I, proemium [a7v]: "non ex eius auctoritate, quia ipse dixit, sed ex evidenti ratione..."

19 Ibid., IV: 334: "Miror sane Philosophos nostros existimare se posse fieri perfectos, sola lectione, \& commentatione, seu speculatione..."

20 Ibid.: "Cum tamen tota physica observationibus innitatur. Quod si dicas, re observationes ab aliis sumere, \& illis experientias relinquere: scito, te illis etiam scientiam relinquere, tibi fidem assumere. Nec enim unquam philosophiam habebis physicam, absque experimentis. Multa ergo dicit hic Aristoteles, \& ex illo sequaces describunt, quae obscura sunt, \& difficultatem habent, \& quia interpretes noluerunt experiri, ne fortasse arguerentur falsitatis, \& cogerentur fateri errorem praeceptoris: cana, \& inepta omnino adduxerunt."
} 
text is the final goal. These adherents to Aristotle think that "Aristotle always tells the truth," and that "it is a kind of blasphemy to affirm that Aristotle did not tell the truth." ${ }^{21}$ Cabeo's description of Peripatetics is hyperbole, having more in common with Galileo's fictional Simplicio than with prominent Peripatetics of the day. Even Cesare Cremonini, the Paduan philosopher who gained notoriety for what he claimed to be literal interpretations of Aristotle, did not maintain that all of Aristotle's precepts were true. In fact, in the prefaces to his commentaries on the De caelo and De anima, he wrote provisos that these interpretations were of Aristotle and not necessarily what he thought to be true, although he perhaps included these warnings only to escape ecclesiastical prosecution. ${ }^{22}$

Despite his reservations about other Peripatetics, Cabeo stressed the importance of accurate analysis of Aristotle's text: "it is primary to know what Aristotle said on each issue, to understand thoroughly his words and the meaning of those words, and to conceive with the entire mind the arguments, which he uses to prove particular issues." 23 Thus a commentator should strive to clarify the text as it stands, not by adding words and phrases, which Cabeo claimed was unfortunately the custom. ${ }^{24}$ However, the understanding of the precise meaning of the text is "primary," and thus the starting point, but not the destination. This

21 Ibid., I: 12: "ita ut Blasphaemia quaedam sit apud ipsos affirmare Aristotelem verum non dicere..."; ibid, "enim semper Aristoteles veram dicet..."

${ }^{22}$ Cesare Cremonini, Disputatio De caelo (Venice, 1613), 350: "Semper hoc constans esto; nos hic non quaerere rei veritatem, at solum Aristotelis sententiam."; Idem, Expositio in III libros De anima, Biblioteca Marciana Ms lat. VI 190 (XVII) as transcribed in Ernst Renan, Averroès et l'averroïsme, $2^{\text {nd }}$ ed., (Paris, 1861), 476-477: "Aristoteles enim unus est homo, et dicit Scriptura: Omnis homo mendax, Deus veritas; quare veritatem ex Deo ipso et ex sanctis hominibus, quid ex Deo, locuti sunt accipere debeamus..."; "scitote tamen quod non sunt multa in quibus Aristoteles dissentit a veritate, et illa non sunt ita demonstrata, ut possint haberi demonstrationum resolutiones." See also: Idem, Apologia dictorum Aristotelis: De quinta caeli substantia (Venice, 1616), 4-5: "Sic est etiam de Aristotele, quem non dico simpliciter veritatem attigisse, quippe qui erravit, quandocumque contra fidem sensit..."

${ }^{23}$ Cabeo, Commentaria, I, proemium [a7v]: "Primum est, quid in qualibet re dixerit Aristoteles cognoscere, eiusque verba, \& verborum sensus penitus intelligere, \& rationes, quas ad singulas res probandas adducit, mente omnino concipere."

24 Ibid.: "Pro meo igitur captu quanta maxima potero claritate, Philosophi sensum apertum reddam, \& quia Aristotelis capita longiora mihi vedentur, per textus distribuam, \& ne sentiam interturbent inserta auctoris verba, adiectis litterulis, ut fere moris est, textum appellabo." 
is why Cabeo divided his work into lectiones, followed by quaestiones. The former were intended to reveal Aristotle's intent accurately, while the latter aimed to go beyond Aristotle and search out the truth unfettered by the demands of ancient authority and bolstered by knowledge derived from the senses. Aristotle's doctrines are not "dogma brought down from the sky," but if "one wants to advance towards knowledge, one must examine them against the standard of truth, discuss each unshrouded proposition very accurately, expound the force of his reasoning, and expose the causes brought forth from Aristotle himself." ${ }^{25}$

According to Cabeo, many of Aristotle's views could not be accepted because he was "more accustomed to metaphysical speculation, than to physical observation." ${ }^{26}$ In the class of metaphysical speculation, he included abstractions and the unnecessary deployment of scholastic logic that depended on reducing things (res) to universal categories, differences, and divisions, all three of which have no physical reality. He rejected metaphysical entities as chimerical because they are neither material nor physical. ${ }^{27}$ Cabeo's attack on metaphysics has much in common with the positions of later thinkers who were openly hostile to Aristotelianism. Joseph Glanvill, for example, chastised metaphysical entities as "chimaerical" because they cannot be observed. ${ }^{28}$ Robert Boyle, who apparently read at least portions of the Commentaria, called Cabeo an "inquisitive Peripatetic" and "one of the most judicious" commentators because of his observation that faithful

25 Ibid.: "Hoc ubi egerit, hanc Aristotelis sententiam, non tamquam e caelo delatum dogmam, debet venerari, nec tamquam rem sacrosanctam suscipere, si nos ad scientiam deducere vult, sed ad veritatis normam examinare debet, accuratissime propositionem ipsam nudam discutere, rationum momenta expendere, causas ab ipso etiam Aristotele alatas perpendere."

26 Ibid., IV: 418: "Sed etiam hic videtur Aristoteles magis metaphysicis speculationibus assuetus, quam physicis observationibus."; IV: 79-80: "unde cum Aristoteles physicum agit, omnino antiquos sequitur, sed quia iste Philosophus maxime pollebat ingenio metaphysico, \& apprime arridebat philosophari per metaphysicas abstractiones, reducendo semper res ad universalissimas, \& metaphysicas rationes, ut constat in tota eius physica; imo \& in tota morali, \& poetica, \& rhetorica ipsa; semper enim res deducit ad differentias, divisiones, \& metaphysicas abstractiones.”; IV: 351: “omnino Aristotelis ingenium erat ad subtilitates metaphysicas, \& abstractiones: non concrescebat illa subtilitas ingenii, ut concrescunt physica."

27 Ibid, I: 114: "sed videant ne physicam reliquant philosophiam, ut chimaeras sectentur metaphysicas."; III: 406: "illud est materia, non chimaerica, sed physica."

28 Joseph Glanvill, Scepsis scientifica (London, 1661), 111. 
adherents to Aristotle use metaphysics as an interpretative crutch, claiming that Aristotle shifts between "actu E potentia... to shift off those Difficulties he could not clearly Explicate." ${ }^{29}$ Boyle's complaints about scholastic philosophy touched on Cabeo's major themes. For both Boyle and Cabeo natural philosophy should avoid metaphysics and be based on observations of the physical world. Boyle wrote:

And indeed the doctrines of Forms \& Qualities, and Generation \& Corruption, and Alteration are wont to be treated of by Scholastical Philosophers, in so obscure, so perplex'd, and so unsatisfactory a way, and their Discourses upon these Subjects do consist so much more of Logical and Metaphysical Notions \& Niceties, then of Physical Observations and Reasonings... ${ }^{30}$

Therefore, blind faith in Aristotle and dishonest sophistry were to blame for the frequent metaphysical interpretations of natural philosophy. Similarly, according to Cabeo, reasoning (ratio) and especially experience of sensible causes were essential for making progress in natural philosophy and freeing oneself from the dogmatic faith of Aristotle. ${ }^{31}$ The concern with the unnecessary abysses of metaphysics, the physical world, and experience is common to his earlier work. In the preface to the Philosophia magnetica, he claimed that he did not "think that any person can aspire to the dignity of being a philosopher, even if he should muster up some metaphysical subtleties, unless he should have accumulated in his mind the physical and sensible causes of these things, which are produced daily by nature." 32 Thus his reform was intended to correct both Aristotle's commentators, who were consumed by bookish reading, and Aristotle himself who was consumed by metaphysics.

Cabeo's distrust of metaphysical abstraction mirrored his skepticism toward the application of mathematics to physics. While

${ }^{29}$ Robert Boyle, Origin of Forms and Qualities in The Works of Robert Boyle, ed. Michael Hunter and Edward B. Davis (London, 1999), 5:294-295.

30 Ibid., 5:289.

31 Cabeo, Commentaria, I:324: “... alii Philosophi causam inquirunt, supponentes rem esse verissimam, quasi Aristoteles a nullo unquam potuerit decepi. Ego, vero, qui in rebus physicis, \& in Philosophia non fide procedendum puto, sed experientiis, \& rationibus: nec video inter principia scientiarum poni fidem..."

32 Cabeo, Philosophia magnetica, [a3r]: "Nec enim puto philosophi personam quemquam posse pro dignitate sustinere, etiam si metaphysicas quasdam subtilitates percalleat; nisi illarum rerum, quae a natura quotidie passim producuntur, physicas, \& sensibiles causas, in quibus ingenium acquiescat, possit afferre, non quod illas metaphysicas speculationes non suspictam, non admirer, non toto pectore hauriendas censeam;" 
recognizing the internal certainty of mathematical proof, he maintained that nature could not be reduced to mathematical forms. ${ }^{33}$ Cabeo's doubts over the validity of mathematics have their roots in positions on the epistemic status of mathematics that were developed among Jesuits in the sixteenth century. By the middle of the sixteenth century, questions on the certainty of mathematical demonstration were proliferating throughout Italy. ${ }^{34}$ The Jesuit Benito Pereira, in his frequently reprinted $D e$ communibus omnium rerum naturalium principiis (1576), contended that because quantity was distinct from sensible substances, mathematics could not give demonstrations that were potissimae. Thus he concluded that subjects that depended on the notion of quantity, that is, mixed mathematics, were not proper sciences. ${ }^{35}$ Geronimo Hurtado, a student of Pereira, furthered this point: "However much they are said to consider the formal cause, the mathematical sciences do not consider truly and properly any cause." ${ }^{36}$ True sciences must go beyond mathematics and look to sensible matter.

Mathematical explanations suffer because they, like metaphysical speculations, do not consider physical things. According to Cabeo, often the application of "quantity is not physical but metaphysical." As a result of the gap between these abstractions and the material world, mathematical explanations are unsatisfactoy. For example, in his discussion of the rainbow, he conceded that mathematical proofs are valid in terms of argument but that they do not explain the facts of the rainbow in physical terms: "The demonstrations are good and geometrical, but they do not explain the rainbow, nor the cause of its roundness, and they do not address the issue, because perhaps these authors were too pure mathematicians and did not adjust their proofs to accommodate physical things." ${ }^{37}$ The modesty of physicists (physici) to

${ }^{33}$ Ibid., 211: "Non possum hoc dictum ad Mathematicam redigere formam, tum quia physicum totum hoc est negotium."

${ }^{34}$ For an overview of the history of this question in the sixteenth century, see: Anna De Pace, Le matematiche e il mondo (Milan, 1993).

35 Rivka Feldhay, "The Use and Abuse of Mathematical Entities," in Cambridge Companion to Galileo, ed. Peter Machamer (Cambridge, 1998), 92-93.

${ }_{36}$ From his Conclusiones mathematicae, 151, quoted in Romano Gatto, Tra scienza e immaginazione: Le matematiche presso il collegio gesuitico napoletano (1572-1670 ca.) (Florence, 1994), 20.

${ }_{37}$ Cabeo, Commentaria, III: 186: "Demonstrationes ergo bonae sunt \& geometricae; sed non explicant iridem, nec causam rotunditatis \& non sunt ad rem, 
recognize the extent of their science is admirable. Cabeo wrote: "But to the contrary, physicists do not dare to give judgment on a mathematical proof, as I see so frequently happen with mixed mathematicians." 38 In his eyes, mathematicians would do well to follow Aristotle's injunction against metabasis; they ought to keep to mathematical issues. The subject of mathematics is not sensible physical entities, and for the scope of Cabeo's physica it was fairly irrelevant. While the application of mathematics to the natural world is often seen as a hallmark of the development of new natural philosophies during the seventeenth century, it was crucial neither to Bacon's natural histories nor to many of the developments in chymical theory and practice to which Cabeo subscribed. ${ }^{39}$

\section{Chymical corpuscularism}

Cabeo used alchemical theory as a basis for physica because it provided, instead of metaphysical principles, physical ones that referred to sensible bodies; he thought its content was verifiable by careful observation if not by experiments. Cabeo adopted the physical principles of alchemical theory and used them to develop a corpuscular matter theory independent from the concept of substantial form, a concept that he considered metaphysical and therefore beyond the boundaries of physica. In particular, there are numerous affinities between Cabeo's understanding of hylomorphism and the matter theory put forth in Geber's Summa perfectionis, a work that Cabeo read and cited. ${ }^{40}$ Both Geber and Cabeo used the position of particles instead of substantial forms to explain the characteristics of material substances. ${ }^{41}$ Cabeo

\& quia fortasse auctores nimis puri erant Mathematici, non adverterunt suas demonstrationes rei physicae non accomdari."

38 Ibid.: "Contra vero physici non sunt ausi iudicium ferre de demonstratione mathematica, ut video frequenter contingere in mathematicis mixtis." On modesty as a virtue prized by Jesuit authors, see: Michael John Gorman, "Mathematics and Modesty in the Society of Jesus: The Problems of Christoph Grienberger," in New Science and Jesuit Science: Seventeenth Century Perspectives, ed. Mordechai Feingold (Dordecht, 2002), 1-121.

39 For mathematics and its relevance to chymistry see: Newman and Principe, Alchemy Tried in the Fire, 58-68.

40 William R. Newman, The Summa Pefectionis of Pseudo-Geber: A Critical Edition, Translation and Study (Leiden, 1991). Cabeo cited Geber at Commentaria, IV: 356.

${ }^{41}$ On Geber's abandonment of the concept of substantial form see: William 
understood substances to be composed of "subtle and spiritous parts" that are "fixed" in a wet medium, which serves as a "union" by employing links (vincula) composed of stable thick parts. The spirits are composed of small and active parts of matter, while that which is fixed is "thick, still, earthy, ashy, solid, never evaporates," ${ }^{22}$ and "always remains heavy and falling." ${ }^{43}$ Despite being material, according to Cabeo the "spiritous part should be called called form," because it is responsible for the union of the other particles. Instead of matter, privation, and form, we are left with a wet medium equivalent to "union," heavy and fixed parts (matter), and spirits (form).$^{44}$

Cabeo's debts to alchemy did not end with Geber; he also adopted Paracelsus' theory that metals are composed of salt, mercury, and sulfur. The wet medium corresponds to mercury, the spirits are sulfur, and the fixed parts are salt. ${ }^{45}$ For Paracelsus the three components of matter corresponded to the Trinity and thus were imbued with religious meaning. To the contrary, Cabeo stressed the physical nature of these parts: "these are the three true physical principles." ${ }^{46} \mathrm{He}$ emphasized that the spiritous and fixed parts were "physical and real." ${ }^{47}$ They are also sensible, and Cabeo claimed that he learned of their properties through repeated observation. Although spirits are furtive and "often elude the senses," he informed the reader that these parts of matter are observable whenever the bonds of a mixture are destroyed and the spirits fly away. ${ }^{48}$

R. Newman, Promethean Ambitions: Alchemy and the Quest to Perfect Nature (Chicago, 2004), 74-76.

${ }^{42}$ Cabeo, Commentaria, I: 14: "Est praeterea altera pars fixa, crassa, manens, terrea, cinericia, consistens, quae nunquam evanescit."

43 Ibid., I: 113: "semper remanet gravis, \& cadens."

44 Ibid., I: 407: "in universum pars spiritosa dicetur forma, fixa est vera materia, humiditas est physica, \& vera unio, qua forma unitur materiae."

45 Ibid., I: 406: "a sapientioribus pars spiritosa dicitur sulphur; fixa dicitur sal, \& humiditas vocatur, Mercurius.”; I: 114: "Humiditas ergo, quam, si non haberes aliam vocem, a Chymicorum vocibus vocabis Mercurium, est vinculum illius, \& ligamen, quo sulphur, hoc est spiritosa, \& vivida illa pars, quae in resolutione abit in auras, \& subtile effluvium, coniungitur cum sale, hoc est cum parte illa fixa, stabili, \& consistente, quae semper remanet, \& in perfecta resolutione nunquam resolvitur."

46 Ibid., I: 406: "haec sunt tria vera principia physica."

47 Ibid., I: 114: "physicae, \& reales sunt partes..."

48 Ibid., I: 14: "Probatur hoc experientia quoties quamcumque ratione destruitur quodlibet mixtum semper duas istas partes observabis, alteram quae avolat, alteram quae refidet, \& quamvis spiritosa illa furtim se subducat, \& sensum saepe 
Cabeo's commitment to using only real and physical entities greatly altered the traditional way of understanding substantial change, generation and corruption, and the nature of mixture. For Aristotle, bodies were composed out of mixtures of the four traditional elements. When completely mixed, a new substantial form either supervened on or replaced the forms of the elements. Mixtures were considered to be perfect, when the supervening substantial form was fully realized, and imperfect when only partially. ${ }^{49}$ For Cabeo, however, generation, corruption, and the perfection of mixtures were considered exclusively in terms of the three kinds of matter. Generation is the result of spiritous particles becoming fixed in a medium; and, destruction occurs when these particles depart or fly away from the heavier particles and their binds dissolve. True physical generation occurs when the volatile subtle parts that were once separate from the fixed parts are glued by the intervening humor. "This," wrote Cabeo "is a true physical mixture, and it becomes perfect, when there is a concoction of its wetness, by which the spiritous parts are joined with the fixed." ${ }_{50}$ Perfection is not the realization of an essence or purpose but rather the result of the firmness of the link: "The perfect composition [perfecta compositio] of all sublunary substances is such because their parts are joined with a perfect link." The stronger the link, the more perfect the mixture. ${ }^{51}$ On the other hand, the corruption of substances is caused by the weakening of the binds that cause the "spirits and subtler parts to separate from the corporeal, and the thick and still ones to

eludat." Ibid.: "Mihi sensata experientia ostendit omnia mixta constare ex duplici Physicae parte quarum una est subtilis, spiritosa, quae facile in auras abit."

49 For Aristotle's distinction between mixture and combination, see: Harold H. Joachim, “Aristotle's Conception of Chemical Combination," Journal of Philology 29 (1904), 72-86. For early modern debates over the destinction of these terms see: Christoph Lüthy, "An Aristotelian Watchdog as Avant-Garde Physicist: Julius Caesar Scaliger," Monist 84 (2001), 542-561.

50 Cabeo, Commentaria, IV: 84: "Haec est vera generatio physica, de quae hic Philosophi, quod nimirum partibus fixis; iterum volatiles aliae separatae adiungantur, \& convenienti humore adglutinentur, \& haec vera physica mixtio, \& perficitur, ut constabit ex infra dicendis, concoctione illius humidi, quo partes spiritosae, cum fixis coniunguntur, \& tota perfectio, vel imperfectio mixti consistit in ista meliori, vel peiori concotione.

51 Ibid., IV: 98: "Tota rerum sublunarium perfecta compositio in eo consistit, ut partes sint perfecto vinculo copulatae, \& quo magis coniunctae fuerint, \& minus separabiles, etiam ab efficaciori agente, diceretur certe res magis perfecta, in ratione unius, \& compositi; istam autem partium compositionem, seu colligationem, dixi iam saepe fieri in humido." 
descend, while the subtle ones go up into the air." ${ }^{52}$ Neither generation nor corruption truly adds or subtracts anything; they are merely the division and union of parts. ${ }^{53}$

Geber similarly described composition in terms of the strength of the resulting union that prevents the substance's particles from separation. Cabeo's use of the word compositio also resonates with Geber, and reveals that Cabeo's mixtures, just as Geber's, were not true mixtures, that is, they were compounds in which the parts can be differentiated. ${ }^{54}$ Rather than being a truly homeomerous substance, a mixture or a composition has distinguishable parts: spirit, wet particles, and heavy particles, all of which are bound together. They unite, but they do not change their substance. Using another Gerberian term, Cabeo wrote that a mixture is formed through the combinations of the smallest particles (per minima permixta), as he understood that only when the spirit had thoroughly penetrated the wet medium could the fixed parts become linked..$^{55}$

As a result of his commitment to explaining the characteristics of all sublunary bodies throught the combining of corpuscles, the common understanding of form as essence was mistaken, in

${ }^{52}$ Ibid., IV: 80: "Dico ergo, ut saepe indicatum est, \& non semel etiam fusius explicatum, rem aliquam corrumpi, nihil aliud esse, quam ex attenuatione humidi, quasi ex dissolutione vinculi separari spiritus, \& partes subtiliores, a corporalibus: \& crassas, \& consistentes concidere, subtiles in auras abire."

53 Ibid.: "ut in corruptione nihil deperditur, sed quae erant unita dividuntur; in generatione nihil producitur, sed quae erant divisa uniuntur."

54 See: Newman, "Experimental Corpuscular Theory," 294.

55 Cabeo, Commentaria, IV: 99: "Dum ergo partes spiritosae, ut ad rem revertur, alicuius compositi sunt commixtae cum fixo, sed humidum remanet adhuc aqueum, facile calore avolat aqua, \& ita compositum dissolvitur: unde si mixtio dicitur perfecta, \& mixtum perfectum, quando non qualibet vi potest dissolvi, debet eo res redigi, ut non ita facile humidum possit avolare: debet ergo illa humiditas, quae dicebatur humiditas quanta, \& aquea, quia non erat incorporata partibus componentibus, sed solum quasi localiter, \& per minima permixta, bene incorporari, \& uniri, interna penetratione, \& identificatione, ut iam fiat humidum quale, \& oleaginosum, \& hic transitus fit per calorem semper, nec alio fere modo natura hoc assequitur, qui calor in principio debet esse temperatus, \& moderatus; dum enim illo moderato calore attenuatur humiditas, ex una parte non avolat, quia non redditur nimis tenuis; ex alia redditur magis apta, ut spiritus illam pervadere possint, tota sua substantia: \& ita illa humiditas redditur magis spiritualis, \& redditur ipsa magis apta, ut intime pervadet ipsum corpus, \& acquirit ingressum, dum redditur magis penetrativa, \& subtilis, \& ita illi intime partes fixae copulantur, \& dum hoc perpetua \& continuata actione fit, hoc modo corpus sit spirituale, \& spiritus corporeus, \& dum sic humiditas perficitur, \& intimius unitur cum partibus, dicitur fieri concoctionem, proprie \& vere." 
Cabeo's view; rather forms are a certain type of real, physical, material entities, namely spirits and vapors that have various powers and virtues. ${ }^{56} \mathrm{He}$ dismissed the Stagirite's understanding of substantial form, because it "is a metaphysical essence and formula according to Aristotle; it is not a physical entity" ${ }^{57}$ and therefore has no role in natural philosophy. The twin concepts of form and privation, as traditionally understood, are also rejected, "one of which is nothing, the other metaphysical." 58 Cabeo's corpuscular philosophy redefined form as active and physical. He wrote:

But the true physical form is that vapid and subtle spirit, which gives determined being to each thing. For a thing is this or that because it is animated by this or that spirit. From this this [spirit], there is an active force of such quantity and of such kind; and just as the diversity of the sublunary objects comes from these diverse spirits, which are implanted in them, the diversity of faculties, properties, operations and virtues comes from these. This is true act, this true form, not a metaphysical reason conceived by the mind, but the physical principle of the faculties. ${ }^{59}$

What Aristotle called form, and what some consider metaphysical, is in fact a specific kind of body that unifies the substance. It is a spirit, a vapor that consists of small parts. Like the Stoics, Cabeo's form is an active, and entirely material, force that orders the world and its contents. ${ }^{60}$

${ }^{56}$ I disagree with Ugo Baldini's interpretation of Cabeo's hylomorphism. Baldini argues that Cabeo thought that forms and matter were not names of specific physical bodies and that they had a metaphysical meaning: they were names of names, or names of classes. While all categories are in a sense metaphysical, form and matter are categories of physical substances for Cabeo, whereas for most Aristotelians, substantial forms are metaphysical essences of substances. Cf. Ugo Baldini, "L'evoluzione della 'fisica' dei gesuiti in Italia, 1550-1700: un approccio strutturale," in Saggi sulla cultura della Compagnia di Gesù (secoli XVI-XVIII) (Padua, 2000), 275-277.

57 Ibid., IV: 80: "\& sic fortasse forma substantialis, est essentia \& ratio metaphysica apud Aristotelem. Non entitas physica."

${ }_{58}$ Ibid., I: 406: "non forma, \& privatio, quorum alterum nihil est, alterum quid metaphysicum."

${ }_{59}$ Ibid., III: 4: "forma vero physica est ille, spiritus vapidus, \& subtilis, ille enim est, qui dat rei unicuique determinatum esse. Ideo enim res est talis, quia tali spiritu animatur. Ab isto est vis activa, tanta, \& talis; \& sicuti diversitas harum rerum sublunarium provenit a diversis istis spiritus, qui rebus inditi sunt; ita diversitas facultatum, proprietatum, operationum, virtutum, ab iisdem prodit. Hic vero verus actus, haec vera forma, non metaphysica, mente concepta ratio, sed physicum principium facultatum."

${ }_{60}^{60}$ Cabeo does not use the world "pneuma," but there are similarities between his form and that of the Stoics, see: Stoicorum veterum fragmenta, ed. Hans Friedrich August von Arnim (Leipzig, 1903-1924), 439-462. For Stoic influences in the seventeenth century, see: Peter Barker, "Stoic Contributions to Early Modern 
The innovations in Cabeo's matter theory did not end in his rejection of the traditional understanding of substantial form; he also rejected the four traditional elements and integrated the Paracelsian prima tria with the more Aristotelian earth, water, and spirit. He claimed that his use of only three elements was not a refinement of Aristotelian theory or a new philosophy, but came from the Philosopher himself. He wrote: "This is true Peripatetic doctrine, here expressly handed over by Aristotle, so that you do not think that I have forged a new philosophy, but I repeat the very thing from Aristotle which Aristotle took from the ancients." ${ }^{11}$ The evidence in this case is textual, as Cabeo took a unique interpretative position. The supporting passage, which comes from the fourth book of the Meteorology, reads:

Therefore, the homeomerous bodies both in plants and animals consist of water and earth. And what are metals, such as gold, \& silver, and whatever else of this sort, [consist] of these [water and earth] and an exhalation, either of which, is enclosed [within the earth] as is stated in other places. $^{62}$

Equating the circling vapors, described as smoky and moist that Aristotle called the double exhalations and considered responsible for atmospheric and subterranean change, with spirits, and taking the phrase "homeomerous bodies" to mean "all homeomerous bodies," Cabeo concluded that all sublunary substances are composed out of earth (fixed parts), water (the wet medium), and the double exhalations (spirits), and that these are the "true elements." He wrote: "I think that Aristotle, whatever other interpreters say, spoke universally about all things, not just about some, and he concludes that all homeomerous bodies are made of four bodies, earth, water, and the double exhala-

Science," in Atoms, Pneuma, Tranquillity: Epicurean and Stoic Themes in European Thought, ed. Margaret J. Osler (Cambridge, 1991), 135-154; Gad Freudenthal, "Clandestine Stoic Concepts in Mechanical Philosophy: the Problem of Electrical Attraction," in Renaissance and Revolution: Humanists, Scholars, Craftsmen, and Natural Philosophers in Early Modern Europe, ed. J. V. Field and Frank A. J. L. James (Cambridge, 1993), 161-172.

${ }^{61}$ Cabeo, Commentaria, IV: 342: "ista est vera doctrina peripatetica, hic expresse a Aristotele tradita; ut videas me novam non procudere philosophiam: sed eandem, quam Aristoteles desumpsit ab antiquis ab Aristot. repetere."

62 384b30-34. Cabeo used William Moerbeke's translation: Commentaria, IV: 342: Text XXV: "Ex aqua igitur, \& terra, similarium partium corpora constant \& in plantis \& in animalibus. Et quae metalla sunt. Ut aurum, \& argentum, \& quaecunque alia talia. \& ex ipsis \& exhalatione ea, quae utriusque, inclusa, sicut dictum est in aliis." 
tion." ${ }^{63}$ For Cabeo, the double exhalations are the spirits that define the diverse number of sublunary bodies through active powers. ${ }^{64}$

While his reframing of the Aristotelian elements depended on textual explication, more often Cabeo appealed to the sensible world to support his corpuscular matter theory. Knowledge of spirits is gained from experience, albeit not experimentation. Vegetable spirits unite the material of plants and give it life, just as animal spirits, "as experience establishes," give life to animals. ${ }^{65}$ Upon death these spirits break up and separate themselves from the body, although Cabeo cautioned that "it may not that the [intact] soul of a horse or a dog flies away, rather the spirits having been broken-up move away and disperse." ${ }^{66}$ The existence of spontaneous generation supports these claims, according to Cabeo. He argued that animals that are produced without seed are created in dung, which contains animal spirits that had previously been separated from living animals. Similarly, worms are generated out of rotting meat, which is "filled with animal spirits" that still adhere to the carcasses of the once living organisms. ${ }^{67}$

Cabeo's appeal to simple everyday experience in establishing the existence of vegetable and animal spirits is not indicative of the varied range of observations and experience he utilized in his Commentaria. Experience for Aristotle and most Aristotelians

63 Cabeo, Commentaria, IV: 342: “puto ego Aristotelem, quicquid dicant alii Interpraetes, loqui universaliter de omnibus, non de aliquibus tantum, \& concludit, quod omnia corpora similaria constant ex quatuor corporibus, ex terra, \& aqua, \& ex duplici exhalatione."

64 Ibid., IV: 346: "Nam diversitas specifica corporum pendet ex diversitate harum partium, \& praesertim, ex diversitate illorum halituum, quos ponit Aristoteles quamvis enim uno nomine communi vocentur halitus, haec tamen est ratio generica, \& in singulis rebus diversae speciei sunt, isti halitus: \& licet etiam pars fixa fortasse sit diversa; tamen istae halitus certe est diversus, \& ex istis vere constituuntur res eiusdem vel diversae speciei. Non a rationibus abstractis per intellectum metaphysice..."

${ }^{65}$ Ibid., IV: 81: "Ex animali expirant spiritus animales, \& sensitivi, per continuam transpirationem corporum, ut constat experientia..."

66 Ibid.: "Cum enim dissolvitur aliquod vivens, \& aliquod animal, id contingit, ut dictum est, quia illis spiritus, qui coniuncti cum illo fixo, formabant illud vivens, attenato humido separantur, \& avolant; non avolant autem coniuncti, \& ita non potest dici avolare anima equi, aut canis sed avolant divulsi, \& distantur, ac disperduntur."

67 Ibid., IV: 82: "Hinc vides cur facilius generentur vermes ex carne putrescente aut ex simili materia; quia, scilicet, illa materia est magis referta spiritibus animalibus." 
was a broad category that included commonplace or quotidian experiences, which included observational facts that were thought to be accepted universally. Additionally the category of experience included other people's experiences or accounts of them found in authoritative books; an experience cited need not be based on the author's own observation. Cabeo, however, discounted the role of everyday experience (experientia quotidiana), and chastised Aristotle for his dependence on it. Instead he claimed: "A philosopher will never become a scientific physicist (physicus scientificus) only by reading books of philosophy, unless he considers nature, and takes up experiments experimenta sumat)." ${ }^{68}$ Thus he urged natural philosophers to rely on their own observations and actively experience and intervene in nature instead of relying uniquely on experiences contained in texts.

Both Renaissance Aristotelians and seventeenth-century Jesuits have been credited with promoting empiricism in natural philosophy. Eckhard Kessler has argued that a movement away from metaphysics toward experiential knowledge characterizes a number of thinkers participating in or influenced by Renaissance Aristotelianism, while Peter Dear has located the rise of mathematical experimentalism in the works of various seventeenth-century Jesuits. ${ }^{69}$ Cabeo's reliance on chymical testing and experience differs significantly from both of these groups.

Dear contends that a group of Jesuits, inspired by a reading of Posterior Analytics 2.19, emphasized the role of sensation in forming universal concepts that were considered the basis of scientific knowledge. ${ }^{70}$ Among some of these Jesuits, this interest in experience and experimentalism became intertwined with a reliance on mathematical proof to determine certainty. Again, Cabeo does not fit well with this group. First, while maintaining the

68 Ibid., IV: 353: "nec Philosophus erit unquam physicus scientificus, solum legendo libros philosophorum, nisi ipsam naturam consideret, \& experimenta sumat."

${ }^{69}$ On the division between metaphysical and empirical versions of Aristotle during the Renaissance, see: Eckhard Kessler, "Metaphysics or Empirical Science? The Two Faces of Aristotelian Natural Philosophy in the Sixteenth Century," in Renaissance Readings of the Corpus Aristotelicum, ed. Marianne Pade (Copenhagen, 2001), 79-101. See Antonino Poppi, Introduzione all'aristotelismo padovano, $2^{\text {nd }}$ ed., (Padova, 1991), 13-44, for a characterization of Paduan Aristotelianism as privileging experience at the expense of metaphysics.

70 Dear, Discipline and Experience, 42-46. 
importance of induction, he rejected the importance of using logic and forming universals in physica, thereby limiting the need to appeal to the Posterior Analytics. Second, Cabeo distrusted the mixing of the mathematical with the sensible worlds. His empiricism derived instead from the Geberian alchemical tradition. Both medieval and early modern practitioners of alchemy had developed techniques of assaying and contrived interventions into nature that were integrated with Aristotelian concepts. ${ }^{71}$ It is in this tradition that Cabeo urged scientific physicists to take up experiments, so that by doing their own laboratorial research they could understand the works of nature. In Baconian-sounding language he urged the use of experiments in order to break away from bookish knowledge and directly confront the natural world. He claimed that to learn the components of some substance, the surer method involves looking at the substance itself rather than to consult others; and it is even surer, he suggested, "to penetrate to the interior of nature." 72

Accordingly, some of his experiments set out to correct Aristotle. For example, Aristotle explained the ability of wax and metal to compress upon pressure by the presence of invisible pores into which the sensible parts recede upon pressure. Cabeo rejected Aristotle's supposed claim that the entire body becomes smaller. To be fair, Aristotle did not actually contend that the size of metal changes in such circumstances. ${ }^{73}$ Nevertheless, according to Cabeo, he erred because he was not sophisticated in making observations: "what Aristotle says is based on everyday experience (experientia quotidiana), which we must not defer to because of what is said by someone else." ${ }^{\prime 4}$ In his view, a more sophisti-

71 William R. Newman, "Art, Nature, and Experiment among some Aristotelian Alchemists," in Texts and Contexts in Ancient and Medieval Science, ed. Edith Sylla and Michael McVaugh (Leiden, 1997), 305-317; William R. Newman, "Experimental Corpuscular Theory;" id., Promethean Ambitions, 238-289.

72 Cabeo, Commentaria, I: 12: "Hoc non tam ex libris, aut dictis sapientum, quam ex oculari Philosophia dicere possumus, dum enim quaero ex qua re aliquid constet, \& ex quo componatur tutius fortasse erit rem intueri, quam aliquem interrogare, in hoc enim non quaerimus placita hominum, sed naturae opus. Verum quidem est, si non valemus per nos ipso hoc investigare, vel de nostris experimentis diffidimus aliorum observationibus insistendum, \& experientias observandas; caeterum sensu, quo manu ducent ad naturae penetralia pervenire tutissimum est..."

${ }^{73}$ Mete. IV, 386a17ff.

${ }^{74}$ Ibid., IV: 393: "nam etiam ferrum est pressibile, \& signabile, quid, quid dicat Aristoteles, ut constat experientia quotidiana, quam non debemus deferere propter dictum alicuius hominis." 
cated test reveals that the body does not in fact contract. He argued that compressed bodies expand in the opposite direction of the pressure so that there is no sensible diminishment in magnitude. He described his experiment as such:

I have proven this by experiments on lead and on other metals, by testing the magnitude of a lead ball with water, as has been described in other places. If it is beaten into a thin sheet, and again its magnitude is tested, there will be no loss at all of its magnitude from the change of shape made by the contusion. But it will conserve the same magnitude in the thin sheet, which it possessed as a ball. And this is true, and derived from experiment, for this fact neither must Aristotle be consulted, nor any other philosopher, but experience itself. ${ }^{75}$

Thus, Cabeo claimed to show that metals do not compress internally, but only change shape.

At times Cabeo's experimental method was imprecise and broad despite his call for active intervention into nature. While he stressed individual experiences and did not develop a system for collective experimentation, he agreed with some of the observational results of his contemporaries, particularly results from astronomy. For example, he accepted the existence of sunspots, new stars, and superlunary location of comets ${ }^{76}$ and was particularly impressed by the replicability of the observations of Tycho Brahe, whom he claimed had been capable of making his measurements "not once, or twice, but as frequently as needed." 77 Nevertheless he insisted that descriptions of observations in books could not be trusted completely. Even one's own observations and experiments are imperfect and their results liable to correction. He admitted that if someone should put forth better experiments than previously conducted he would change his mind,

75 Ibid.: "Probavi hoc experientia in plumbo, \& in aliis metallis, explorata enim per aquam, ex alibi dictis, globi plumbei magnitudine. Si contundatur in laminam, \& iterum exporetur eius magnitudo, constabit nihil penitus magnitudinis esse deperditum, ex mutatione figurae, per contusionem facta; sed eandem magnitudinem conservare in lamina, quam possidebat in globo. \& hoc est verum, \& constat experientia, nec de hac re consulendus est Aristoteles, aut alius philosophus, sed experientia ipsa."

${ }^{76}$ Ibid., I: 16: "ex modernis omnes, qui putant ex novis Phaenomenis, ex cometis, \& novis stellis, ex maculis Solis, \& aliis observari in caelo mutationes.”

77 Ibid., I, 172: "Ex quo constat ipsum mensurasse singulorum planetarum distantiam a terra, non semel, aut bis, sed frequentissime quantum requirebatur, ut posset pronuntiare, quando nam sint in maxima elongatione a terra, quando in minima, \& quanta sit haec distantia." See: Dear, Discipline and Experience, 127129, for Cabeo's privileging of the replicability of experiences. 
because experimental conclusions are not proven to the same extent that mathematical propositions are. ${ }^{78}$

While the replicability of Tycho's observations was attractive, Cabeo championed above all chymical practice as ideal for penetrating into nature because of its ability to find the principles of nature by "dissolving things and disjoining their composing parts." Alchemists were " true physical philosophers" (veri Philosophi physici). ${ }^{79}$ The breaking down of substances illuminated their internal composition. Cabeo described his own attempts to break down substances, which confirmed his belief that matter was composed of thick and subtle parts. For example, puzzled by what causes lightning to fall to the earth, he attempted to illustrate that previously invisible heavy matter emerges from some substances when burnt. Arguing that it is the impetus of these partes crassiores that causes lightning's rapid descent to the earth, he offered the reader an experiment, which he claimed to have performed in front of Duke Ferdinando Gonzaga. By heating purged saltpeter and submerging it in water, Cabeo claimed to show that previously occluded thick parts emerged, resulting in a heavy residue, thereby offering an analogy to the physical changes of lightning. ${ }^{80}$ In another example, Cabeo recommended ars sublimatoria to break down oil into its wet medium and a powder. While he did not narrate the perfomance of experiment, as in the previous example, he noted that this process was "observed by an exact experiment (experimenta)," and then cited the chymical author Joannes Mylius as also having known this procedure. ${ }^{81}$

78 Cabeo, Philosophia magnetica (Ferrara, 1629), 195: "Sed si quis prius meliora, \& magis experimentis congruentia attulerit; etiam ego libenter sententiam mutabo; nec enim ista, ut mathematice demonstrata profero." Cf. Peter Dear, "Jesuit Mathematical Science and the Reconstitution of Experience in the Early Seventeenth Century." Studies in the History and Philosophy of Science 18 (1987), 172.

${ }^{79}$ Cabeo, Commentaria, IV: 244: "puto illos [Chimicos] esse veros Philosophos physicos, qui ex propriis principiis rerum naturas venantur. nec potest quis melius scire, ex quibus nam res constent, tamquam ex elementis, quam si res ipsas dissolvat, \& partes componentes disiungat."

${ }^{80}$ Ibid., III: 26-27: "Hac occasione do tibi lector pulcherrimum experimentum, \& eius subtexo rationem, ut videas spiritum tenuem, si inflammetur, non habere sensibilem impetum, nisi dum coniungitur cum materia aliquanto crassiore, Summe salnitrum repurgatum, \& in crucibulo igne fusionis accende..." For a similar chymical explanation of lightning and thunder, see: Daniel Sennert, Epitome naturalis scientiae (Oxford, 1632), 267-268.

${ }^{81}$ Ibid., IV: 315: "\& hoc exacta experientia observatum est, \& notavit etiam Milius, in sua Basilica chymica.” 
While it has been argued that there was insufficient empirical evidence for seventeenth-century atomism and corpuscularism, Cabeo would have disagreed. Like the rest of his physica, his matter theory derived from his interactions with the sensible realm. ${ }^{82}$

The application of corpuscular materialism and its observational basis, however, had their limit, namely the human soul, a realm in which experimentation is difficult. According to Cabeo, "In mankind, not only are there these spiritous substances [animal and vegetable] but there is also another spiritual substance, which is not spiritous and vapid, but is truly in its substantial being something altogether different from body." ${ }^{33}$ Unfortunately, the ramifications of this dualism are not discussed, as he left those for discussions of "the books of the De anima," of which he authored none. What remains clear is that for Cabeo all substances from the lowest up to but not including the human soul were generated from the position and combination of thin vapid parts, thick parts, in a watery medium.

\section{Conclusion}

At first glance, Cabeo's corpuscularism, his rejection of substantial forms, and his insistence on using three Paracelsian elements seem to be far removed from the exigencies of commenting on Aristotle. It is tempting to ask: What does any of this have to do with Aristotle? The answer is comes from his selection of the Meteorology; Cabeo, although he thought experiential evidence was paramount, also believed he had support in Aristotle's own writings. The ability of Cabeo to produce a reformed Aristote-

82 Christoph Meinel, "Early $17^{\text {th }}$-century Atomism: Theory, Epistemology, and the Insufficiency of Experiment," Isis 79 (1988), 68-103; Catherine Wilson, "Corpuscular Effluvia: Between Imagination and Experiment," in Wissensideale und Wissenskulturen in der frühen Neuzeit, ed. Wolfgang Detel and Claus Zittel (Berlin, 2002), 161-184, esp. 169.

${ }^{83}$ Cabeo, Commentaria, IV: 82: "In homine vero, non solum sunt istae substantiae spiritosae, sed est praeterea alia substantia spiritualis, quae non est spiritosa, $\&$ vapida, sed est vere in suo esse substantiali aliquid omnino diversum a corpore, \& substantia spiritualis, quae, quia unitur corpori ad complendum principium unius operationis, ad quam operationem necessario praerequiritur corpus, \& quia ex sua natura est talis, \& facta est ut uniatur corpori, ad perficiendam istam operationem; ideo dicitur forma informans \& vere est informans, \& ens incompletum, in ratione illius principii, sed haec pluribus ad libros de anima." 
lian natural philosophy removed from metaphysical and mathematical speculation depended on his choice of text. That one of his two published works was on the Meteorology was both slightly unusual and an important step to transforming Aristotelian natural philosophy into a field concerned with the physical and sensible. Because of its dependence on material and efficient causation the Meteorology is perhaps the most suitable of Aristotle's books for creating an Aristotelian natural philosophy strictly concerned with the material world. Aristotle argued that material and efficient causes were the best explanations for changes in the sublunary region and omitted explanations dependent on formal and final causes, the very explanations that were the targets for Descartes and Bacon, among others. ${ }^{84}$ Choosing the Meteorology as the basis for Aristotelian natural philosophy, was most likely a conscious choice to replace the Physics. The topics of the Meteorology include the motion of the sun, the double exhalations that cause atmospheric changes, the effects of heat and cold on material substances, the secondary properties of substances, in sum sensible things; on the other hand, the Physics is concerned with the conceptual tools to understand nature. Thus in this work Aristotle wrote on a large number of abstract concepts, such as the definition of nature, change, matter and form, potency and act, the four causes, time, space, continuity. Cabeo was fully aware that interpretations of the Physics, unlike those of the Meteorology, necessarily must address numerous topics beyond the sensible realm. ${ }^{85}$

Moreover, by exclusively commenting on the Meteorology, Cabeo was actively subverting the commentary tradition of Jesuits during the late Renaissance, which had increasingly emphasized metaphysics. Leading scholastic authors such as Benito Pereira, Suárez, Toletus, and Fonseca did not comment on this work and instead wrote extensively on ontology and natural theology. ${ }^{86}$

84 Aristotle, Meteorology, 339a20-33.

${ }_{85}$ Cabeo, Commentaria, I, 9: "si non sint sensibiles in se non erunt causae Physicae, neque vero aliquem moveat, quod videat in libris Physicorum a Philosopho, aliquando aliqua examinari, quae sensibilia non sunt."

${ }^{86}$ For the increased interest in metaphysics among Iberian Jesuits see: Charles H. Lohr, "Les jésuites et l'aristotélisme du XVIe siècle," in Les jésuites à la Renaissance: Système éducatif et production du savoir, ed. Luce Giard (Paris, 1995), 79-91; Charles H. Lohr, "Metaphysics," in Cambridge History of Renaissance Philosophy, ed. Charles B. Schmitt, Quentin Skinner, Eckhard Kessler, and Jill Kraye (Cambridge, 1988), 537-638, esp. 606-620. 
Thus his book was an attempt to correct the "many Peripatetics occupied in these metaphysical subtleties [who] do not read these books [the Meteorology]." ${ }^{87}$ By commenting on the Meteorology, Cabeo could both promote his version of Aristotelian chymistry and easily engage with recent developments in natural philosophy.

One does not necessarily associate the field of meteorology with the most significant developments in natural philosophy during the seventeenth century, or really for any century. The lack of ready associations between great changes in science and meteorology, however, is unwarranted. Aristotelian meteorology was defined as the study of the area between the moon and the center of the earth where the elements were in a state of constant flux, in contrast to the celestial regions where bodies were unchanging and moved regularly. A number of the challenges to Aristotelian philosophy were based on undermining the distinction between sublunary and superlunary. These challenges included Galileo's discovering of sunspots and seemingly terrestrial features, such as mountains, on the moon, and the contention that comets were celestial bodies. Other notable contestations against Ptolemaic geocentrism, such as Galileo's explanation of the tides, were meteorological. Thus a commentary on the $M e$ teorology allowed Cabeo to address many of these issues, and in fact he accepted that the heavens were subject to generation and corruption on the basis of observed sunspots, comets, and new stars. ${ }^{88}$ Moreover, Cabeo's use of the Meteorology as a vehicle for the reformulation of natural philosophy was not unique for the seventeenth century: Descartes' Les Météores was an attempt to provide an alternative to the Coimbra College's fully Aristotelian

87 Cabeo, Commentaria, IV: 352: "Sed istos libros non legunt multi peripatetici occupati in illis subtilitatibus metaphysicis."

88 For his acceptance of the corruptibility of the heavens see: Cabeo, Commentaria, I: 15-17. Cabeo addressed sunspots in that quaestio at Commentaria, I: 17; see Commentaria, I: 170-179 for a discussion of Tycho's and Scipione Chiaramonti's understandings of comets; Chiaramonti, who defended the position that comets are sublunary, responded to Cabeo's criticism in his: De sede sublunari cometarum et novorum phenomenon libri duo: in primo continetur defensio sententiae suae ab oppugnationibus P. Nicolai Cabaei (Forlì, 1648). For Tycho's status among Jesuits see: Michel-Pierre Lerner, "L'entrée de Tycho Brahe chez les jésuites ou le chant du cygne de Clavius," in Les jésuites à la Renaissance: Système éducatif et production du savoir, ed. Luce Giard (Paris, 1995), 145-185. See: Commentaria, IV: 264 for Cabeo's discussion of the topography of the moon and Venus. 
meteorological text book. ${ }^{89}$ Jean-Baptiste Du Hamel's De meteoris et fossilibus (1660), in turn, was based on Aristotelian principles, yet devoted many pages to chymistry. ${ }^{90}$ And, well after Cabeo's death, university lectures on the Meteorology continued to import material from new philosophies, such as those of Descartes and Newton, to students in Italy. ${ }^{91}$

Moreover, notoriously, the fourth book of the Meteorology has been interpreted as promoting atomism and corpuscularism. Throughout the twentieth century, classicists and philosophers argued over whether the discussion of pores in this book referred to truly empty interstitial spaces, voids, and thereby suggested the book's inauthenticity. ${ }^{92}$ During Cabeo's time, its authenticity was not in question. ${ }^{93}$ Nevertheless, scholars were aware that this book could be interpreted as atomistic. A century before Cabeo, Pietro Pomponazzi, claiming that Aristotle "Democrizat," wrote in his commentary on Meteorology IV: "I would say

89 Étienne Gilson, "Météores cartésiens et météores scolastiques," in Études sur le rôle de la pensée médiévale dans la formation du système cartésien $5^{\text {th }}$ ed. (Paris, 1984), 102-137; Collegium Conimbricense, In quatuor libros de Coelo, Meteorologicos, E Parva Naturalia, Aristotelis Stagiritae (Venice, 1606). The Coimbra work on the Meteorology, despite its title, is not a commentary but rather a treatise composed of four books each devoted to one of the elements. Gilson noted the structural similarities between Descartes' and the Coimbra meteorologies.

${ }^{90}$ Jean-Baptiste Du Hamel, De meteoris et fossilibus (Paris, 1660). Lengthy discussions of chymistry are found at: 98-182, 283-310.

${ }_{91}$ Brendan Dooley, "Science Teaching as a Career at Padua in the Early Eighteenth Century: The Case of Giovanni Poleni," History of Universities 4 (1984), 127135. For attempts to reconcile Aristotle and the new natural philosophy of the seventeenth century see: Christia Mercer, "The Seventeenth-Century Debate between the Moderns and the Aristotelians: Leibniz and Philosophia Reformata," Studia Leibnitiana Supplementa 27 (1990), 18-29; L. W. B. Brockliss, "Aristotle, Descartes and the New Science: Natural Philosophy at the University of Paris," Annals of Science 38 (1991), 33-69.

${ }_{92}$ The debate began with: I. Hammer-Jensen, "Das sogenannte IV. Buch der Meteorologie des Aristotles," Hermes 50 (1915), 118-136. A good summary of how the debate has unfolded is found in Hans Strohm, "Beobachtungen zu vierten Buch der aristotelischen Meteorologie," in Zweifelhaftes im Corpus aristotelicum, ed. P. Moraux and J. Wiesner (Berlin, 1983), 94-96; Carmela Baffioni, Il IV libro dei Meteorologica di Aristotele (Naples, 1981) contains abstracts of most contributions to this debate.

${ }^{93}$ In the late fifteenth century, Bernardino di Treviso wrote that some judged Meteorology IV as inauthentic but he disagreed with them. Who these people were remains unknown, see his: Elucubrationes super libros Meteorologicos, Ms. Bologna B U 1664, fol. 265r: "Aliqui arbitrati sunt hunc quartum librum non esse philosophi. Cuius oppositum censeo attamen non insisto circam ipsum quod non ita difficilia tractantur prout in tertio ubi utitur stilo magis probabili quam in quartum." 
that the Philosopher agrees with Democritus, because he concedes [the existence of] pores." ${ }^{.4}$

In addition to potentially promoting a corpuscular matter theory, Meteorolgy IV also lent itself to reframing the traditional four Aristotelian elements, as shown above. Cabeo's revised form of Aristotle stemmed from his exposure to new observations and was confirmed by his particular reading of the Meteorology. The decision to base his natural philosophy around the Meteorology permitted Cabeo to develop an experiential and experimental philosophy that integrated chymical matter theory with the explication of a traditional text. ${ }^{95}$ The large size of the Aristotelian corpus, the numerous unresolved textual puzzles and apparent doctrinal contradictions gave commentators the flexibility needed to find the Aristotle that fit their needs. In the case of Cabeo, it was an Aristotle modified by experience and intertwined with an alchemical tradition that could compete with new natural philosophies that were emerging in the first years of the seventeenth century. At that time, Aristotle could mean innovation as well as tradition.

${ }_{94}$ Pietro Pomponazzi, Dubitationes in quartum librum Meteorologicorum (Venice, 1563), fol. 43v: "ergo Aristoteles Democrizat..., Ego dicerem, quod philosophus assentitur Democrito in hoc, quoniam concedit poros." See also: 47v: "Videtur ibidem Aristoteles Democrizare, nam incidit in quaestionem Democriti. Qui voluit quod actio fiat per poros." See: Lüthy, "An Aristotelian Watchdog ," 544-545.

${ }_{95}$ For the relation of Meteorologyi 4 to alchemy from antiquity through the Middle Ages see the essays: in Aristoteles Chemicus: Il IV libro dei Meteorologica nella tradizione antica e medivale, ed. Cristina Viano (Sankt Augustin: 2002). For the Meteorology as a source for Aristotelian discussion of experiments see: William R. Newman, Promethean Ambitions, 238-289. 